ABDI: Jurnal Pengabdian dan Pemberdayaan Masyarakat

ISSN: 2656-369X (Print), 2684-8570 (Online)

Volume 3 No. 2, Desember 2021

http://abdi.ppj.unp.ac.id/index.php/abdi

Email: abdi@ppj.unp.ac.id

DOI: https://doi.org/10.24036/abdi.v3i2.109

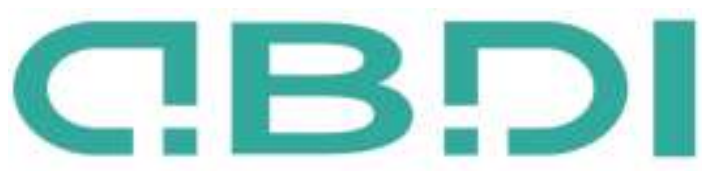

ABDL JURNAL PENGABOIN DAN PEMBERDAYAN MASYARAKAT

\title{
Advokasi Pembentukan Forum Anak Nagari
}

\author{
Nila Wahyuni' ${ }^{1}$ Rahmadhona Fitri Helmi ${ }^{2}$, Artha Dini Akmal ${ }^{3}$ \\ 1,2,3Jurusan Ilmu Administrasi Negara, Universitas Negeri Padang \\ E-mail: nilawahyuni@fis.unp.ac.id, rahmadhonafh@fis.unp.ac.id, arthadiniakmal@fis.unp.ac.id.
}

\begin{abstract}
Abstrak
Salah satu hak anak yang jarang terpenuhi adalah hak untuk berpartisipasi. Anak tidak hanya dilibatkan dalam proses pengambilan keputusan dalam keluarga tetapi juga harus berperan aktif dalam aspek pembanunan. Forum anak merupakan jembatan komunikasi antara anak dan pemerintah untuk berpartisipasi dalam pembangunan Nagari Layak Anak. Nagari Tabek dan Nagari Sawah Tangah di Kecamatan Pariangan, Kabupaten Tanah Datar, mitra pengabdian kami masih belum memiliki forum anak. Hal ini disebabkan beberapa hal: 1) tidak semua anak memahami fungsi dan perannya dalam pembangunan nagari; 2) anak kurang percaya diri dalam menyuarakan aspirasinya; 3) pemangku kepentingan belum menjadikan partisipasi anak sebagai hal yang penting dalam kebijakan pemerintahan nagari. Tujuan dari kegiatan pengabdian ini adalah untuk menyuarakan kepentingan Pengarusutamaan Hak Anak (PUHA) dan menginiasasi lahirnya forum anak nagari. Kegiatan ini dilakukan dengan menggunakan metode pelatihan partisipatif dan kolaboratif. Hasil kegiatan pengabdian menunjukkan bahwa, adanya peningkatan pemahaman stakeholders tentang Pengarusutamaan Hak Anak dan peran forum anak, peningkatan kemampuan anak berbicara di depan umum dalam menyuarakan aspirasi dan kepentingannya, terbentuk komitmen antar stakeholders dengan menginisiasi pembentukan forum anak nagari.
\end{abstract}

Kata Kunci: Collaborative Governance, Forum Anak Nagari, Nagari Layak Anak, Partisipasi Anak

Abstract

One of the child rights that is rarely fulfilled is the right to participate. The child should not only be involved in the decision-making process in the family but must also play an active role in the developmental aspect. The child forum is a bridge of communication between children and the government to participate in the development of a ChildFriendly Village. Nagari Tabek and Nagari Sawah Tangah in Pariangan District, Tanah Datar Regency, our partners still don't have a child forum. This is due to several things: 1) not all children understand their functions and roles in village development; 2) children lack confidence in voicing their aspirations; 3) stakeholders have not made children's participation an important thing in village government policies. The purpose of this activity is to voice the interests of the Mainstreaming of Children's Rights (PUHA) and initiate the birth of the Nagari Children's Forum. This activity is carried out using participatory and collaborative training methods. The results of the service activities show that there is an increase in stakeholders' understanding of the Mainstreaming of Children's Rights and the role of children's forums, an increase in children's ability to speak in public in voicing their aspirations and interests, a commitment is formed between stakeholders by initiating the formation of a Nagari Child Forum.

Keywords: Child Participation, Collaborative Governance, Child-Friendly Village, Nagari Child Forum

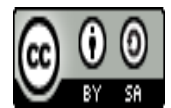

$\begin{array}{lll}\text { Received: } 5 \text { April } 2021 & \text { Revised: } 6 \text { Agustus } 2021 & \text { Available Online: } 25 \text { Agustus } 2021\end{array}$

ABDI: Jurnal Pengabdian dan Pemberdayaan Masyarakat Vol. 3 No. 2 


\section{Pendahuluan}

Anak merupakan investasi bagi keberlanjutan dan kemajuan suatu negara. Di Indonesia lebih dari 35\% penduduknya merupakan anak-anak, yang mana menurut UU No. 35 Tahun 2014 tentang Perlindungan Anak menyatakan bahwa anak adalah seseorang yang belum berusia 18 (delapan belas) tahun termasuk yang masih di dalam kandungan. Semenjak tahun 1989 melalui Konvensi Hak Anak, telah diatur dan dikelompokkan hak-hak dasar anak yang kemudian diratifikasi oleh Pemerintah Republik Indonesia melalui Keppres dan Undang-Undang. Namun sampai saat ini dalam pengimplementasiannya seringkali belum berjalan optimal.

Salah satu hak dasar anak yang masih sulit dipenuhi yaitu hak berpartisipasi. Ini terlihat dari kebijakan serta program pemerintah yang masih menggunakan anak sebagai objek pembangunan dan bukan melibatkan mereka secara aktif dalam proses pembangunan (Devi, Rizki, Sulastri, \& Irfan, 2016). Padahal aspirasi, suara, pendapat, keinginan, serta kebutuhan anak amat diperlukan sebagai masukan bagi pemerintah dalam setiap proses pembangunan di negara ini agar tercipta Indonesia Layak Anak (IDOLA). Oleh sebab itu, perlu adanya sebuah "tools" bagi anak-anak untuk mewadahi hal tersebut.

Forum anak adalah salah satu "tools" yang dapat menjadi wadah bagi anak-anak untuk berpartisipasi. Bentuk partisipasi anak di dalam forum anak ini terdiri dari 3 jenis yaitu sebagai pelopor, pelapor, dan partisipasi dalam perencanaan pembangunan sesuai wilayah forum anak tersebut berada (UU No. 18 Tahun 2019). Kepengurusan anak dalam forum anak dibatasi oleh usia yakni paling rendah 12 tahun dan paling tinggi sebelum 18 tahun (UU No. 18 Tahun 2019). Forum anak inilah yang nantinya akan menjembatani komunikasi dan interaksi antara anak-anak dengan pemerintah dalam rangka pemenuhan hak partisipasi anak. Secara nasional sudah tercatat ada 31 Forum Anak Provinsi, 401 Forum Anak Kabupaten/Kota, 267 Forum Anak Kecamatan, dan 170 Forum Anak Desa/Kelurahan. Jumlah ini terbilang sedikit dibandingkan dengan jumlah total wilayah yang ada di Indonesia saat ini. Hal ini tentu belum sesuai dengan amanat UU No. 34 Tahun 2014 tentang Perlindungan Anak bahwa setiap anak berhak untuk hidup, tumbuh dan berkembang, serta berpartisipasi.

Sumatera Barat merupakan salah satu provinsi yang telah lama membentuk Forum Anak Daerah yakni pada tahun 2007. Kemudian diikuti oleh wilayah lainnya, salah satunya Forum Anak Daerah Kabupaten Tanah Datar yang terbentuk pada tahun 2018 (www.kla.id). Namun dalam implementasinya terdapat beberapa masalah seperti forum anak sampai saat ini belum mampu menjadi media aspirasi anak dalam proses pembangunan. Terbukti dengan belum adanya upaya maksimal antara nagari (desa), kecamatan, dan kabupaten dalam mensinergikan pemenuhan hak anak ke dalam kebijakan daerah. Hal ini bisa terjadi disebabkan oleh model pengelolaan dan perencanaan yang dilakukan pemerintah selama ini masih bersifat sentralistis, top down, dan keengganan pemerintah melibatkan masyarakat dan anak-anak sebagai subjek dalam pembangunan. Di desa atau yang biasa disebut nagari di Sumatera Barat, yakni Nagari Tabek dan Sawah Tangah Kecamatan Pariangan Kabupaten Tanah Datar mitra Pengabdian Kepada Masyarakat (PKM) kami, masih belum memiliki forum anak. Padahal hampir 650 jiwa penduduknya dikategorikan anak-anak, atau hampir 34\% dari total keseluruhan penduduk. Selain itu, Nagari Tabek dan Sawah Tangah juga tidak memiliki fasilitas-fasilitas publik yang bisa dimanfaatkan secara khusus oleh anak-anak, seperti kawasan tanpa asap rokok, pusat kesehatan dan konseling anak, lembaga kesejahteraan sosial anak, dan pusat informasi layak anak yang seharusnya ada dalam rangka pemenuhan dan perlindungan hak anak.

Analisis situasi yang tim pengabdi lakukan bersama kedua Wali Nagari memperlihatkan bahwa rendahnya partisipasi anak dalam pembangunan nagari disebabkan oleh beberapa hal. Diantaranya, pertama, tidak semua anak memahami fungsi dan perannya dalam pembangunan desa; kedua, anak kurang percaya diri dalam menyuarakan aspirasinya; ketiga, pemangku kepentingan belum menjadikan partisipasi anak sebagai hal yang penting dalam kebijakan pemerintahan nagari. Hal inilah yang kemudian membuat

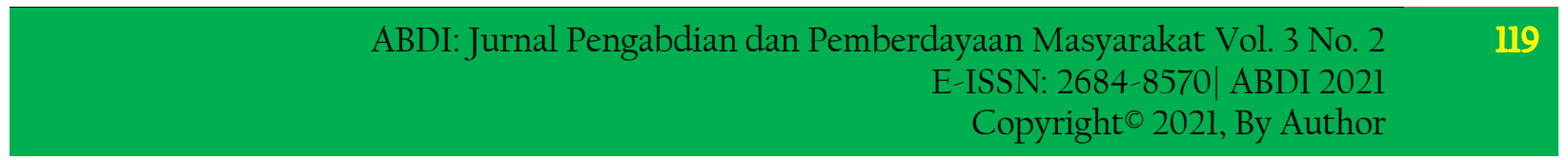


pemerintahan nagari cenderung tidak melibatkan unsur pemenuhan hak anak ke dalam sistem pembangunan nagari.

Masyarakat terutama orang tua masih banyak yang belum mengetahui keberadaan dan fungsi dari forum anak tersebut. Kebanyakan orang tua menganggap bahwa tugas pokok anak hanya belajar di sekolah sementara kebutuhan bersosialisasi di lingkungan belum dianggap sebagai hal urgent. Hal ini menunjukkan bahwa fokus utama pemerintahan nagari masih berbentuk fisik atau infrastruktur, padahal pengembangan sumber daya manusia terutama anak-anak juga tidak kalah penting.

Engagement stakeholders atau keterlibatan pemangku kepentingan terutama anak-anak dalam pembangunan sangat diperlukan karena bukan saja mereka berhak untuk terlibat tetapi juga bermanfaat untuk melahirkan sebuah kebijakan yang partisipatif, kolaboratif, dan inklusif. Bahkan, keberhasilan kolaborasi dapat dilihat dari keterlibatan dan ketertautan nonstate stakeholders di dalam pengambilan keputusan (Ansell \& Gash, 2008) (Ansell \& Gash, 2018) (Emerson, Nabatchi, \& Balogh, 2012). Oleh sebab itu, perlu dilakukan advokasi kebijakan dengan tujuan meyakinkan pemangku kepentingan tidak hanya untuk proses pembangunan semata tetapi lebih dari itu untuk mendukung upaya Pengarusutamaan Hak Anak melalui Forum Anak. Semua pihak yang terlibat secara otomatis akan bertanggung jawab terhadap kebijakan yang telah dirumuskan dan berusaha mencapai keberhasilan kebijakan tersebut.

\section{Metode Pelaksanaan}

Metode pendekatan yang digunakan yakni "pendekatan pelatihan partisipatif dan kolaboratif", yang didasarkan pada prinsip-prinsip parsipatori dengan menekankan kepada asas peran serta seluruh peserta pelatihan agar kegiatan dapat mencapai sasaran dan target yang telah ditentukan. Advokasi pembentukan forum anak nagari ini berbasis collaborative governance dimana stakeholders yang dimaksud tidak hanya unsur pemerintah sebagai institusi publik namun juga unsur non-pemerintah.

Tahapan kegiatan ini dimulai dengan penetapan tujuan pelatihan kemudian diikuti dengan sosialisasi dan advokasi kebijakan oleh tim pengabdi sehingga memberikan suatu hasil yang diharapkan. Advokasi kebijakan ialah tindakan untuk mempengaruhi atau mendukung suatu regulasi atau kebijakan pemerintah maupun seseorang yang bersangkutan dengan kebijakan publik. Metode atau teknik advokasi kebijakan yang dilakukan yaitu seminar/presentasi. Teknik ini biasa digunakan untuk mengadvokasi pejabat publik dari suatu instansi/lembaga tertentu maupun beberapa instansi/lembaga yang berbeda berkaitan dengan permasalahan/isu. Adapun faktor-faktor penting dalam mengefektifkan advokasi kebijakan pada kegiatan ini yaitu: legislasi, kredibilitas, pertanggungjawaban dan kekuasaan (Musdah, 2013). Pelaksanaan kegiatan ini dilakukan dengan teknik antara lain: ceramah; studi kasus; Forum Group Discussion (FGD); praktek dan peragaan; permainan; serta brainstroming.

Tahapan pertama dalam kegiatan pengabdian ini adalah sosialisasi Nagari Layak Anak. Kegiatan ini menyadarkan stakeholders terutama orang tua, Pemerintah Nagari, BAMUS, KAN, tokoh agama, Bundo Kanduang, non-pemerintah dan stakeholders lainnya tentang pentingnya Pengarusutamaan Hak Anak (PUHA). Penyadaran ini penting karena akan menghemat biaya suatu kebijakan karena stakeholders yang telah sadar akan mampu mentrasfer pengetahuannya kepada yang lain.

Langkah selanjutnya memberikan pelatihan public speaking bagi anak-anak di nagari untuk meningkatkan kapasitas mereka berbicara di depan umum dalam menyuarakan aspirasinya. Setelah pelatihan, perwakilan anak diminta untuk mamaparkan aspirasinya dalam sebuah FGD yang diikuti oleh stakeholders kemudian dianalisis permasalahan dan potensinya untuk dirumuskan menjadi isu strategis yang akan diintegrasikan ke dalam sistem pembangunan nagari. Hal ini dilakukan dalam rangka penguatan kapasitas stakeholders terutama pemerintah nagari untuk mampu menghasilkan beberapa pilihan kebijakan dan program yang memenuhi unsur layak anak berdasarkan hasil kesepakatan FGD. Selama kegiatan ini tim melakukan pendampingan dengan melibatkan pakar kebijakan publik yang memantau diskusi sehingga dapat menghasilkan draft isu strategis pemenuhan hak anak.

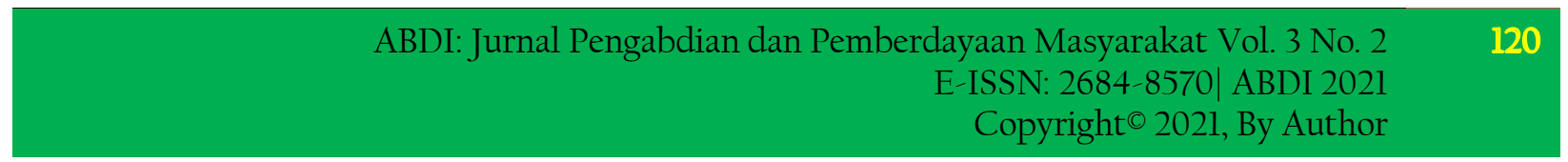


Kegiatan selanjutnya yaitu pendampingan pembuatan draft pembentukan forum anak nagari yang disesuaikan dengan PermenPPPA No. 18 Tahun 2019 tentang Penyelenggaran Forum Anak sebagai landasan hukum terbentuknya Forum Anak Nagari. Tahapan ini didampingi oleh pakar hukum sehingga menghasilkan draft surat keputusan yang sesuai dengan pedoman penyusunan yang memiliki akibat, konsekuensi, serta dapat dipertanggungjawabkan secara hukum.

Semua tahapan tersebut dilaksanakan dengan menggunakan protokol kesehatan. Sebelum kegiatan dimulai semua peserta diukur suhu badannya menggunakan thermal gun dan menggunakan hand sanitizer. Peserta yang memiliki suhu badan diatas 37,3 derajat Celcius tidak diperkenankan untuk mengikuti kegiatan. Semua peserta kegiatan diharuskan menggunakan masker, pelindung wajah, dan duduk berjarak 1,5 meter satu sama lain.

\section{Hasil dan Pembahasan}

Pelaksanaan kegiatan pertama kami lakukan di Nagari Sawah Tangah tanggal 24 September 2020. Setelah itu, kami melaksanakan kegiatan di Nagari Tabek pada tanggal 30 September 2020. Namun, sebelum itu kami sudah melakukan survey awal sebagai tahap persiapan untuk mengetahui persoalan yang akan diselesaikan dengan mitra semenjak awal Agustus 2020.

Partisipasi mitra dalam pelaksanaan program PKM ini adalah sebagai fasilitator sekaligus sasaran dari kegiatan ini. Mitra menjadi fasilitator karena memberikan akses kepada tim pengabdi untuk melakukan kegiatan, serta pihak-pihak lain yang terlibat Kantor Wali Kenagarian Tabek dan Sawah Tangah, BAMUS, KAN, serta juga melibatkan unsur-unsur penting di dalam masyarakat seperti: Tokoh-tokoh Agama, Tokohtokoh Adat, Tokoh-tokoh Pemuda, Bundo Kanduang memwakili perempuan, unsur kependidikan (guru), unsur kesehatan (dokter/bidan). Sedangkan sebagai sasaran yaitu terbentuknya forum anak nagari yang terdiri dari beberapa anak yang menjadi wakil dari keseluruhan anak di nagari.
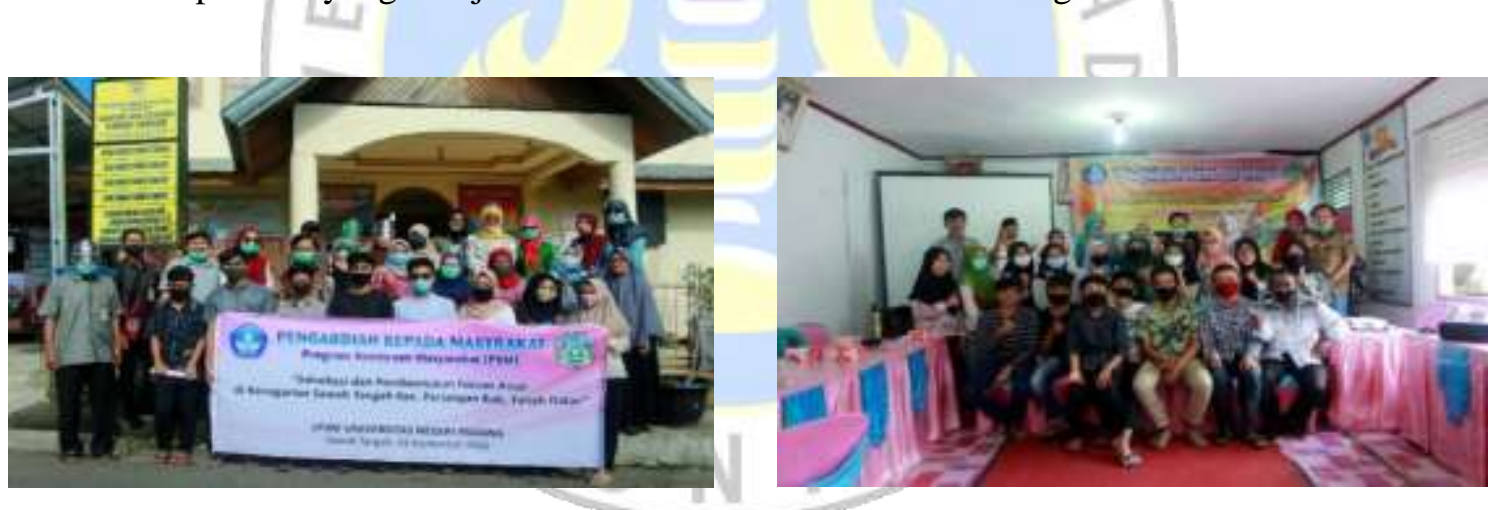

Gambar 1. PKM di Nagari Sawah Tangah (kiri) dan Nagari Tabek (kanan)

Kegiatan pengabdian ini diikuti oleh 40 orang peserta yang terdiri dari berbagai elemen yang terlibat sebagai stakeholders. Tim pengabdian melibatkan narasumber yang dianggap pakar sesuai dengan permasalahan yang ingin diselesaikan. Adapun kegiatan inti dari pengabdian yang kami lakukan terdiri dari 2 bagian besar yaitu sebagai berikut:

\subsection{Sosialisasi Nagari Layak Anak}

Sesi pertama kegiatan dilaksanakan di Nagari Sawah Tangah, materi sesi pertama disampaikan oleh pemateri Yuliarti, S.E., M.E. dan Iip Permana, ST., M.T. Yuliarti menyampaikan, mengacu pada data Sistem Informasi Online Perlindungan Perempuan dan Anak (SIMFONI) Kementerian Pemberdayaan Perempuan dan Anak (Kemen PPPA) sampai tahun 2020 kasus kekerasan pada anak di Indonesia terus meningkat, dimana kasus kekerasan terhadap perempuan dan anak berjumlah 2.416 kasus, dengan rentang 
usia 13-17 tahun yang paling banyak menjadi korban. Fakta ini menunjukkan bahwa anak dan remaja sangat rentan menjadi korban pelanggaran hak asasi.

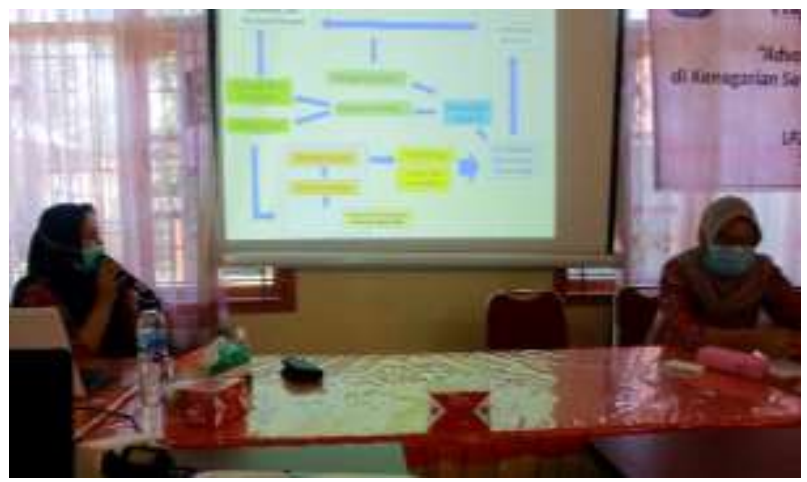

Gambar 2. Deklarasi Hak Asasi Anak yang dijabarkan ke dalam Peraturan PerundangUndangan

Menanggapi hal tersebut tentu negara telah memiliki aturan hukumnya sejak lama. Pemenuhan Hak Anak dan Konvensi Internasional PBB tentang Konvensi Hak Anak telah diratifikasi melalui Keputusan Presiden No. 39 Tahun 1990 dan dijabarkan dalam berbagai peraturan perundang-undangan dan kebijkan terkait anak. Di era otonomi daerah kemudian ditransformasikan ke dalam sistem Pembangunan Berbasis Hak Anak dalam bentuk Desa/Nagari Layak Anak.

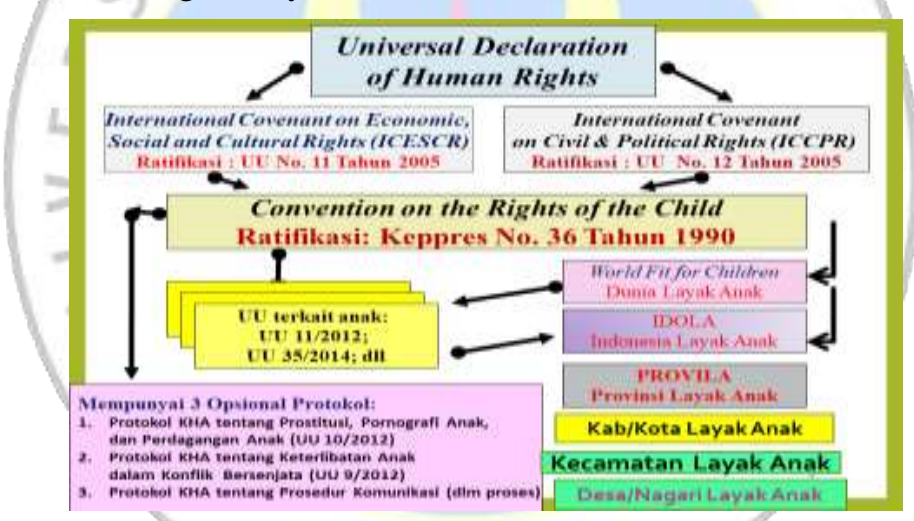

Gambar 3. Penyampaian Materi Sosialisasi Pemenuhan Hak Anak oleh Yuliarti

Meskipun sudah diatur oleh Undang-Undang dan Peraturan Daerah Kabupaten Tanah Datar, perangkat desa di kedua nagari masih tetap memiliki keterbatasan pengetahuan mengenai pentingnya pengembangan Nagari Layak Anak. Yuliarti mengatakan lagi, pemahaman baru ini diperlukan karena telah terjadi pergeseran paradigma. Paradigma pembangunan anak yang sebelumnya bersifat parsial, segmentatif, dan sektoral kemudian bergeser ke arah yang lebih holistik, integratif, dan berkelanjutan. Paradigma baru ini merupakan kombinasi dari bottom-up dan top-down berdasarkan keterlibatan semua pihak (Duadji \& Tresiana, 2018).

Pembangunan kota dan komunitas harus senantiasa diupayakan dengan mengedepankan inklusivitas, keamanan, ketahanan, dan keberlanjutan. Dengan terpenuhinya hal-hal tersebut diharapkan mampu mewujudkan kota yang nyaman, aman dan layak huni sekaligus mampu meningkatkan kesejahteraan bagi warganya (Hikmawan \& Maulida, 2020). Kesejahteraan anak diasumsikan akan terjadi bila pembangunan berjalan dengan baik (Rizki, Sulastri, \& Irfan, 2015). 

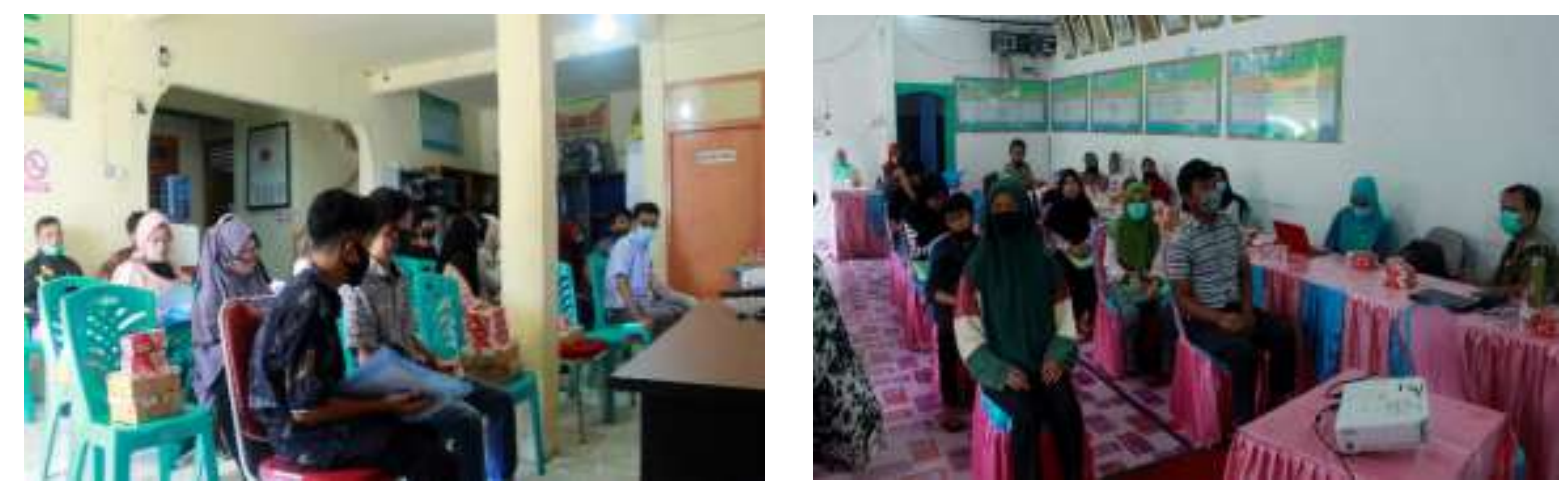

Gambar 4. Kegiatan Sosialisasi Nagari Layak Anak yang Dihadiri oleh Stakeholders yaitu Orang Tua, Pemerintah Nagari, dan Masyarakat

Iip Permana menambahkan, hal ini sejalan dengan pengembangan model tata kelola pemerintahan yang melibatkan multi-stakeholder yang disebut dengan collaborative governance, dimana para pemangku kepentingan duduk bersama untuk menentukan suatu keputusan publik, yang merupakan hasil konsensu s melalui suatu proses dialog tatap muka, pembangunan kepercayaan, dan pengembangan komitmen dan pemahaman bersama (Ansell \& Gash, 2018).

Lebih lanjut Iip Permana menjelaskan lagi, Nagari Layak Anak diartikan sebagai Nagari/Desa yang mempunyai sistem pembangunan berbasis hak anak melalui pengintegrasian komitmen dan sumber daya pemerintah, masyarakat dan dunia usaha, yang terencana secara menyeluruh dan berkelanjutan dalam kebijakan, program dan kegiatan untuk menjamin pemenuhan hak dan perlindungan anak.

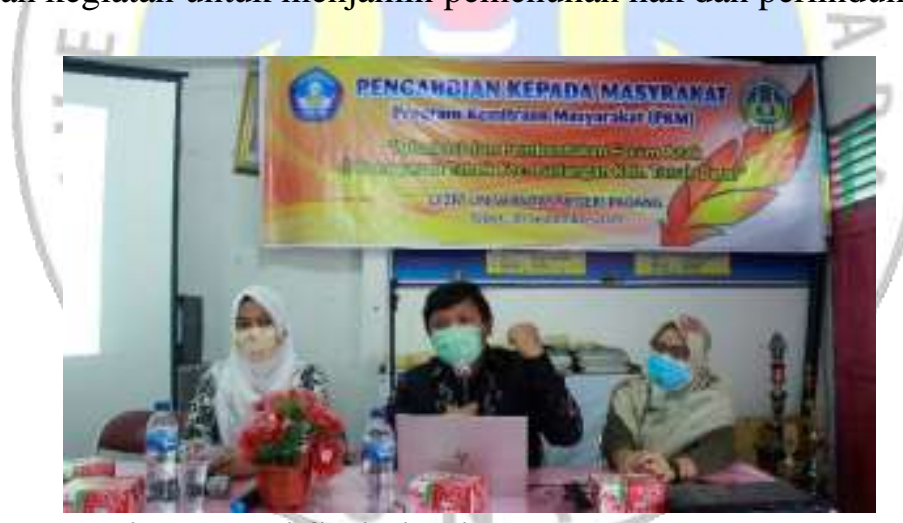

\section{Gambar 5. Penyampaian materi Sosialisasi Peraturan Perundang-Undangan Tentang Anak oleh Iip Permana}

Dari definisi tersebut dapat kita ketahui bahwa stakeholder yang terlibat yakni Walinagari dan jajarannya sebagai unsur pemerintah; BPRN, KAN, perwakilan anak, Dunia Usaha, Lembaga Masyarakat, Media, sebagai unsur non-pemerintah. Iip Permana menambahkan lagi dengan perumusan peraturan nagari haruslah melibatkan multi stakeholder yang berkaitan dan berkepentingan dengan nagari yang layak anak, terutama keterlibatan masyarakat sipil (Fajri et al., 2020). Sehingga, kebijakan yang dilahirkan mendapatkan komitmen yang utuh dari berbagai pihak, tidak hanya berakhir sebagai sebuah dokumen kebijakan. 


\subsection{Advokasi Pembentukan Forum Anak Nagari}

Materi selanjutnya adalah advokasi pembentukan forum anak nagari dan tahapan pembentukan forum anak nagari. Materi sesi ini disampaikan oleh Hidayatul Fajri S.AP., MPA, Yulia Hanoselina, S.I.P., M.A.P., dan Annisa Anindya, S.I.Kom., M.Si. Narasumber pertama Hidayatul Fajri mengatakan, menurut data peraturan nagari yang terdapat di Kabupaten Tanah Datar, sampai saat ini belum menggambarkan kebijakan maupun program nagari yang memprioritaskan hak anak.

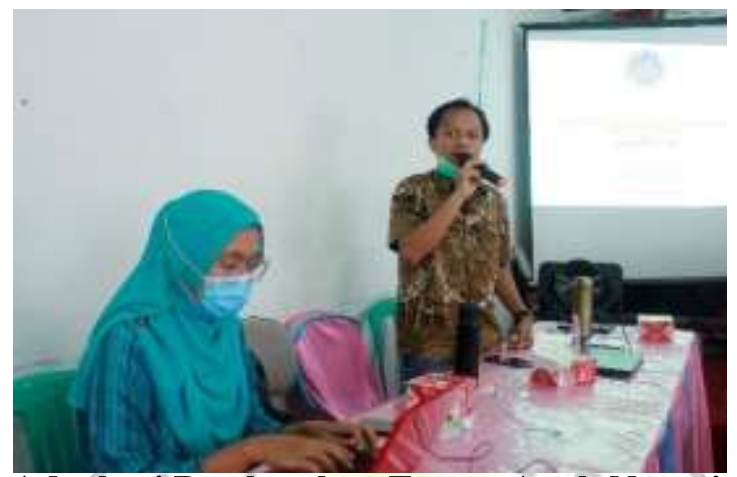

Gambar 6. Adyokasi Pembetukan Forum Anak Nagari oleh Hidayatul Fajri

Belum ada political will yang sungguh-sungguh dari pengambil kebijakan untuk melibatkan anak dalam sistem pembangunan. Budaya formalisme yang begitu kental membuat partisipasi anak sejauh memenuhi aturan formal kebijakan. Salah satu gambarannya yakni peraturan yang ada belum terintegrasi sampai ke tahapan paling bawah yaitu desa/nagari. Hidayatul Fajri menyampaikan lagi dengan mengutip (Augsberger, Springwater, Hilliard-Koshinsky, Barber, \& Martinez, 2019) partisipasi pemuda telah didefinisikan sebagai proses melibatkan anak muda di dalam lembaga dan keputusan yang mempengaruhi kehidupan mereka. Melibatkan kaum muda dalam pengambilan keputusan menjadikan pemuda memiliki keahlian, memberi mereka hak sebagai warga negara, dan bisa mengarah pada masyarakat yang lebih adil dan inklusif (Augsberger et al., 2019). Oleh sebab itu anak-anak memerlukan sebuah wadah untuk berkontribusi baik sebagai pelopor dan pelapor maupun dalam merencanakan pembangunan nagari seperti yang dijelaskan dalam peraturan perundang-undangan. Selanjutnya pelatihan sesi public speaking pada anak yang disampaikan oleh Annisa Anindya. Pada tahapan ini narasumber berusaha memancing antusias anak-anak dengan memberikan metode permainan dan kuis. Saat paparan materi berlangsung anak-anak diberikan sebuah kuis, bagi yang berhasil menjawab dengan benar akan diberikan bingkisan. Metode permainan ini sengaja diberikan narasumber untuk menjadikan anak-anak lebih bersemangat dan rileks dalam mempraktikkan materi yang diterima. Di akhir sesi, anak-anak mempraktikkan dasar-dasar public speaking di depan forum.

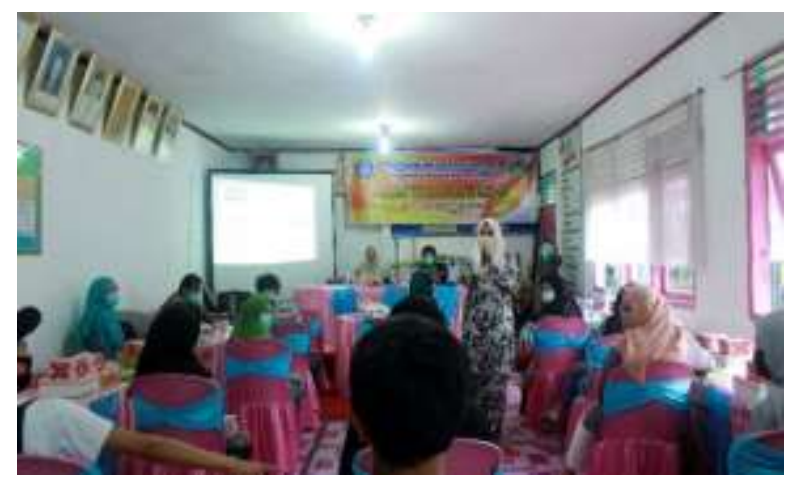

Gambar 7. Pelatihan Public Speaking Bagi Anak-Anak di Nagari oleh Annisa Anindya 
Selanjutnya Forum Group Discussion (FGD) dengan stakeholders untuk merumuskan isu strategis anak yang holistik, integratif, dan berkelanjutan. Dari FGD tersebut didapatkan hasil bahwa selama ini kebanyakan dari stakeholders tidak mengetahui peran partisipasi anak dalam pembangunan nagari. Setelah diberikan pemahaman dan edukasi, para stakeholders berkomitmen mewujudkan peran partisipasi anak melalui forum anak dalam kegiatan dan kebijakan di nagari.

Seperti masalah terbaru yang dihadapi anak-anak di nagari saat ini yakni hambatan saat bersekolah di masa pandemi. Kegiatan pembelajaran sebagian menggunakan sistem daring oleh sebab itu ketersediaan sarana dan prasarana seperti jaringan internet, laptop, dan mobile phone menjadi kebutuhan yang penting. Anak-anak serta orang tua berharap pemerintah nagari bisa menyediakan fasilitas penunjang sehingga mereka bisa tetap dapat memaksimalkan pembelajaran walaupun sedang berada di masa pandemi.

Wali Nagari sebagai pimpinan menanggapi bahwa akan berusaha menampung aspirasi tersebut dengan cara menyediakan fasilitas internet gratis dan ruang baca di kantor Wali Nagari yang sumber anggarannya berasal dari dana desa. Wali Nagari berharap akan terbentuk kelompok belajar di setiap jorong/kampung, sehingga memudahkan siswa/siswi yang ingin berdiskusi dan belajar nantinya.

Selanjutnya penyampaian materi oleh Yulia Hanoselina, yang menjelaskan bahwa terdapat beberapa tahapan untuk membentuk Forum Anak Nagari. Tahapan tersebut terdiri dari persiapan, pelaksanaan, legalisasi, pengukuhan, dan publikasi. Yulia Hanoselina sebagai narasumber mendampingi pembuatan draft Forum Anak Nagari ini dengan mengacu pada PermenPPPA No. 18 tahun 2019. Lebih lanjut dijelaskan bahwa dalam tahapan pembentukan forum anak nagari harus melibatkan stakeholders tidak hanya pemerintah nagari maupun pemerintahan diatasnya, namun juga pelibatan tokoh adat, tokoh agama, dunia usaha, media massa, dan lainnya. Kedua Nagari kemudian mengidentifikasi hasil FGD yang dilakukan secara bersama antara tim, narasumber, dan stakeholders. Hasil tersebut akan dijadikan data awal yang digunakan sebagai naskah akademik untuk diproses menjadi peraturan nagari tentang pembentukan forum anak.

\section{Kesimpulan}

Peningkatan partisipasi anak melalui forum anak merupakan suatu keharusan. Selain tuntutan dari peraturan tingkat nasional dan daerah namun juga menjadi kebutuhan bagi perkembangan suatu negara. Proporsi penduduk kedua nagari yang di dominasi oleh anak-anak menyebabkan pemenuhan hak anak tentu menjadi hal yang krusial. Oleh sebab itu perlu diinisiasi lahirnya forum anak nagari sebagai bentuk pemenuhan hak anak.

Hasil kegiatan PKM di dua nagari menunjukkan hasil yaitu tersuarakannya Pengarusutamaan Hak Anak (PUHA) dan terinisiasinya forum anak nagari. Tiga faktor penting yang mempengaruhi efektifitas advokasi kebijakan dalam kegiatan ini yang pertama yaitu legitimasi. Baik Pemerintah Nagari, BAMUS, KAN, Bundo Kanduang, tokoh agama, dan anak-anak masing-masing berbicara mengenai kepentingannya. Secara personal, orang-orang yang ditunjuk mewakili lembaga-lembaga tersebut diatas telah dilegitimasi melalui mekanisme internal masing-masing lembaga. Kemudian faktor kredibilitas, masing-masing stakeholders tersebut memiliki pengetahuan dan pengetahuan di bidangnya dan telah lama berkecimpung dalam kegiatan maupun kebijakan nagari. Sehingga aspirasi, pernyataan, dan hasil FGD yang telah dipaparkan memiliki kredibiltas.

Faktor penting yang ketiga yaitu kekuasaan, yaitu apa yang dimiliki oleh masing-masing pihak untuk dapat mempengaruhi kebijakan. Pemerintah Nagari, BAMUS, KAN, Tokoh agama, Bundo Kanduang, memiliki kekuasaan jabatan yang dapat mempengaruhi orang tua, masyarakat, dan anak-anak untuk menginisiasi lahirnya forum anak nagari. Anak-anak nagari terutama yang berusia 12-18 tahun yang berperan sebagai pengurus forum anak nantinya memiliki modal yang dapat mempengaruhi stakeholders lain. Hal ini terlihat dari peningkatan pengetahuan dan kemampuan mereka dalam menyuarakan aspirasi dan kepentingan mereka dalam forum setelah dilakukan pelatihan sebelumnya.

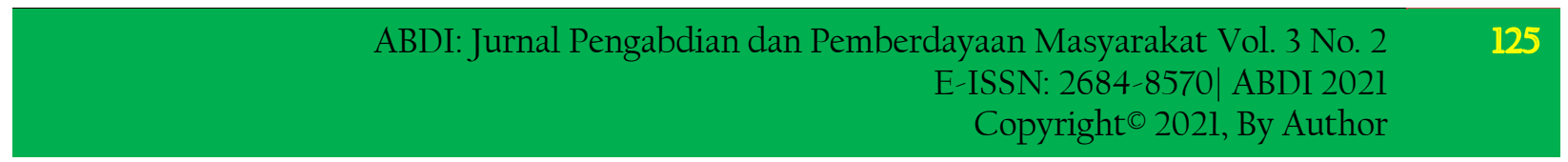


Kemudian terbentuknya draft Surat Keputusan Forum Anak Nagari yang nantinya akan ditindaklanjuti oleh Pemerintah Nagari pada bidang urusan kesejahteraan sosial dan selanjutnya akan disahkan oleh Pembina yakni Wali Nagari. Kemudian hasil kegiatan pengabdian yang utama ialah terbentuknya komitmen antara stakeholders dengan menginisiasi pembentukan forum anak nagari. Hal ini disampaikan secara langsung oleh Wali Nagari sebagai perwakilan dari stakeholders dan berkomitmen untuk menganggarkan dana nagari untuk membentuk forum anak nagari serta pemenuhan hak-hak anak lainnya. Keseluruhan metode dan tahapan kegiatan tersebut akan berjalan efektif jika semua komponen terlibat. Pelibatan aktif seluruh stakeholders menjadi hal yang paling penting di dalam mewujudkan forum anak nagari. Oleh sebab itu perlu pendampingan yang lebih intens oleh pakar terutama pemerintah kota/kabupaten agar peran forum anak nagari nantinya dapat menjadi bahan rekomendasi kebijakan pemerintah yang holistik, integratif, dan berkelanjutan.

\section{Daftar Pustaka}

Ansell, C., \& Gash, A. (2008). Collaborative governance in theory and practice. Journal of Public Administration Research and Theory, 18(4), 543-571. https://doi.org/https://doi.org/10.1093/jopart/ mum032

Ansell, C., \& Gash, A. (2018). Collaborative platforms as a governance strategy. Journal of Public Administration Research and Theory, 28(1), 16-32. https://doi.org/https://doi.org/10.1093/jopart/ $\operatorname{mux} 030$

Augsberger, A., Springwater, J. S., Hilliard-Koshinsky, G., Barber, K., \& Martinez, L. S. (2019). Youth participation in policy advocacy: Examination of a multi-state former and current foster care youth coalition. Children and Youth Services Review, 107(1), 104491. https://doi.org/https://doi.org/ 10.1016/j.childyouth.2019.104491

Devi, O., Rizki, A., Sulastri, S., \& Irfan, M. (2016). Pemenuhan Hak Partisipasi Anak Melalui Forum Anak dalam Implementasi Kebijakan Kota Layak Anak di Kota Bandung:(Studi Kasus Forum Komunikasi Anak Bandung). Prosiding Penelitian Dan Pengabdian Kepada Masyarakat, 360.

Duadji, N., \& Tresiana, N. (2018). Kota Layak Anak Berbasis Collaborative Governance. Sawwa: Jurnal Studi Gender, 13(1), 1. https://doi.org/https://doi.org/10.21580/sa.v13i1.2201

Emerson, K., Nabatchi, T., \& Balogh, S. (2012). An integrative framework for collaborative governance. Journal of Public Administration Research and Theory, 22(1), 1-29. https://doi.org/https://doi.org/ 10.1093/jopart/mur011

Fajri, H., Akmal, A. D., Saputra, B., Dt. Maani, K., Permana, I., Wahyuni, N., \& Syafril, R. (2020). Peningkatan Keterlibatan Stakeholder Dalam Perumusan Peraturan Nagari Layak Anak. Dinamisia: Jurnal Pengabdian Kepada Masyarakat, 4(4), 754-761. https://doi.org/https://doi.org/10.31849/ dinamisia.v4i4.4550

Hikmawan, R., \& Maulida, R. A. (2020). Peningkatan Kapasitas Forum Anak Tangsel Mengenai Pembangunan Kota dan Komunitas Berkelanjutan. Dinamisia: Jurnal Pengabdian Kepada Masyarakat, 4(3), 539-549. https://doi.org/https://doi.org/10.31849/dinamisia.v4i3.3356

Musdah, E. (2013). Advokasi Kebijakan Penetapan Upah Minimum Kabupaten Sleman Tahun 2013. Jurnal Ilmu Pemerintahan, 6(2), 123-136.

Rizki, D. A., Sulastri, S., \& Irfan, M. (2015). Pemenuhan Hak Partisipasi Anak Melalui Forum Anak Dalam Implementasi Kebijakan Kota Layak Anak Di Kota Bandung. Share: Social Work Journal, 5(1), 360-362. https://doi.org/https://doi.org/10.24198/share.v5i1.13085 